\title{
Marine pollution effects of pulp and paper industry wastes
}

\author{
T. H. Pearson \\ Scottish Marine Biological Association, Dunstaffnage Marine Research Laboratory; \\ P. O. Box No. 3, Oban, Argyll, Scotland
}

\begin{abstract}
The scale of waste discharges to the marine environment from the pulp and paper industry in various parts of the world is outlined and a brief description of the major characteristics of such wastes is given. The information available on the direct toxicity of these wastes to marine fauna and flora is assessed including both lethal and sublethal effects. The environmental impact of waste discharge and subsequent ecosystem modifications are considered in detail; the complex adjustments to the nutrient and carbon budgets of the water column and sediment involved in direct alterations to their oxygen balance and other indirect eutrophication effects are described. It is concluded that whereas the direct toxicity of these wastes has minimal effect in the marine environment the complex problems created by increasing the oxygen demand of the receiving waters can have considerable impact in inshore areas. Methods of minimising the effect of such impacts and of forecasting their extent are outlined.
\end{abstract}

"He saw its excreta poisoning the seas. He became watchful" (Hughes, 1970).

\section{INTRODUCTION}

The pulp and paper industry uses a multiplicity of processes in order to reduce raw wood and other types of vegetable material to usable fibre. Essentially all these processes are designed to separate the cellulose component from the remainder, which may be as much as fifty percent of the raw material. Although part of this rejected material may be used in some systems to fuel the process, much of it is inevitably disposed of as waste and thus constitutes a considerable effluent problem. The scale of the problem in so far as it affects the marine environment in various parts of the world may be appreciated from a consideration of the information given in Table 1, taken from the OECD report "Pollution by the pulp and paper industry" (1973). Although there are many mills in continental Europe, very few of these discharge to marine waters, whereas in Scandinavia mills creating forty percent of production discharge their effluent to the sea. In Britain wastes from two thirds of the total production are discharged to the marine environment, amounting to some 100,000 tonnes of suspended solids annually. Table 1 also lists the summary projections given in the report for production and effluent discharge levels for 1975 . It can be seen that although production was expected to increase in most areas, most notably in Scandinavia and Japan, the waste discharge levels were expected to decrease considerably, because of the implementation of 
Table 1. Production, waste discharge levels and proportion discharged to marine waters in the pulp and paper industry in various parts of the world (1975 figures based on estimated projections: taken from the OECD report, 1973)

\begin{tabular}{|c|c|c|c|c|c|c|c|c|}
\hline \multirow[t]{2}{*}{ Area } & \multirow[t]{2}{*}{$\begin{array}{c}\text { Number } \\
\text { of } \\
\text { mills }\end{array}$} & \multicolumn{2}{|c|}{$\begin{array}{c}\text { Production } \\
\text { (in tonnes } \times 10^{6} \text { ) }\end{array}$} & \multirow{2}{*}{$\begin{array}{c}\text { Percent } \\
\text { increase } \\
\text { in production } \\
\text { ('70-'75) }\end{array}$} & \multicolumn{2}{|c|}{$\begin{array}{l}\text { Suspended } \\
\text { solids } \\
\text { discharged } \\
\text { (tonnes } \times 10^{6} \text { ) }\end{array}$} & \multicolumn{2}{|c|}{$\begin{array}{l}\text { Proportion of } \\
\text { production } \\
\text { discharged } \\
\text { to marine waters }\end{array}$} \\
\hline & & 1970 & 1975 & & 1970 & 1975 & $\%$ & $\begin{array}{c}t \times 10^{3} \\
(1970 \text { fig. })\end{array}$ \\
\hline \multicolumn{9}{|l|}{ Continental } \\
\hline Europe & 1492 & 21 & 26 & 24 & 0.7 & 0.45 & 5 & 35 \\
\hline Scandinavia & 316 & 22 & 30 & 36 & 0.5 & 0.3 & 40 & 200 \\
\hline British Isles & 167 & 5 & 5 & 0 & 0.15 & 0.1 & 66 & 100 \\
\hline North America & 1037 & 74 & 87 & 18 & 1.7 & 0.8 & 35 & 595 \\
\hline Japan & 681 & 16 & 23 & 44 & 0.75 & 0.4 & 53 & 400 \\
\hline
\end{tabular}

pollution control legislation which was either being introduced or was already in force in all the areas under consideration at the time of the report.

The general problems associated with discharging pulp and paper mill wastes to the aquatic environment have recently been comprehensively reviewed by Poole et al. (1978). These authors have summarized data on the direct effects of pulp and paper mill wastes on fish and macrofauna with emphasis on the design and utility of various types of bioassay and sensitivity tests; they discuss fully the difficulties inherent in maintaining an adequate oxygen balance in the receiving waters and describe in general terms the ecological changes associated with effluent inputs. However much of their emphasis is of necessity on the problems of discharge to fresh waters; it is the intention of this account to redress this balance somewhat, by concentrating entirely on the marine environment and discussing in some detail the changes brought about in the sedimentary ecosystem by the addition of cellulose waste products. Initially, however, some brief mention will be made of the general characteristics of the effluents concerned, of direct and indirect toxicity effects and of some general effects on the overlying marine water column.

\section{CHARACTERISTICS OF PULP AND PAPER MILL WASTES}

Pollution problems in the industry can arise at all stages in the various processes from initial timber handling to final product refinement. The difficulties associated with timber handling revolve around the settlement of large fragments of bark and wood, up to and including sunken logs, on to marine sediments primarily in log collecting areas. Conlan \& Ellis (1979) have recently shown that this can lead to deoxygenation and elimination of sediment macrofauna and suggest that, should large accumulations of material have built up, recolonisation of such areas may take decades even after the prevention of any further input. Waldichuk $(1978,1979)$ has discussed the general environmental problems associated with log handling and suggested some practical ways of alleviating these. 
Problems associated with pulping encompass the full range of environmental hazards posed by the industry. These can be broadly categorized in four groups viz. problems associated with suspended solids deposition, toxicity, biological oxygen demand (BOD) of dissolved organics and discoloration of the water column. Only the first two are of importance in the paper manufacturing side of the industry. Table 2 lists the major types of manufacturing process, identifies which of the four categories of hazard are of importance in each process, and lists the mean effluent volume and pollution level for each process. The effluent volume produced from these processes and the hazards associated with its discharge differ with each procedure. Thus soda pulping produces some fifteen times more effluent volume than ground wood pulping, which, however, poses a greater hazard from suspended solids. Large modern mills are predominantly either of the kraft or sulphite type. The former pose problems with all four major hazards, but sulphite mills produce a higher effluent volume, although only suspended solids and BOD are of particular importance in effluent disposal from such mills. The various causative factors underlying each of the four major categories of pollution hazard are given in Table 3. No more detailed analysis of the effluent characteristics of the industry will be given here. Further general information may by sought in the review by Poole et al. (1978) or in the technical literature (e. g. Gehm, 1973).

Table 2. Pollution hazards associated with different manufacturing processes in the pulp and paper industry (taken from Poole et al., 1978, OECD report 1973 and Commission of the European Communities Technical Report 1974). SS: Suspended solids; BOD: dissolved organic component; T: toxicity; C: discoloration, the more asterisks the greater the hazard

\begin{tabular}{|c|c|c|c|c|c|c|c|c|}
\hline \multirow[t]{2}{*}{ Process } & \multirow[t]{2}{*}{ Treatment } & \multirow{2}{*}{$\begin{array}{c}\text { Median } \\
\text { effluent } \\
\text { volume } \\
\left(\mathrm{m}^{3} / \mathrm{t}\right)\end{array}$} & \multicolumn{4}{|c|}{ Effluent problem } & \multicolumn{2}{|c|}{$\begin{array}{l}\text { Mean pol- } \\
\text { lution level } \\
(\mathrm{kg} / \mathrm{t})\end{array}$} \\
\hline & & & SS & BOD & $\mathrm{T}$ & $\mathrm{C}$ & SS & BOD \\
\hline \multicolumn{9}{|c|}{ Pulping } \\
\hline Raw kraft (sulphate) & $\mathrm{NaOH}+\mathrm{Na}_{2} \mathrm{~S}$ & 80 & $j^{* *}$ & $* *$ & ** & ** & 15 & 140 \\
\hline Bleached kraft & $\left.\mathrm{NaOH}+\mathrm{Na}_{2} \mathrm{~S}+-\mathrm{Cl}_{2}\right\}$ & & & & & & 45 & 190 \\
\hline Raw sulphite & $\mathrm{Ca}\left(\mathrm{NH}_{3}, \mathrm{Mg}, \mathrm{Na}\right) \mathrm{SO}_{3}$ & 100 & $j^{* *}$ & $* * *$ & * & * & 55 & 350 \\
\hline Bleached sulphite & $"+{ }^{-} \mathrm{Cl}_{2}$ & 170 & & & & & & \\
\hline Soda pulp & $\mathrm{NaOH}$ & 270 & $* *$ & $* *$ & $* *$ & $*$ & 45 & 200 \\
\hline Semi-chemical & $\begin{array}{l}\text { Mechanical + partial } \\
\text { digestion by any of } \\
\text { above }\end{array}$ & 42 & ** & $* *$ & * & * & 45 & 190 \\
\hline Ground wood & Mechanical & 17 & $* * *$ & & & & 30 & 10 \\
\hline & Fine paper and tissue & 50 & $* *$ & & $*$ & * & & \\
\hline \multicolumn{2}{|l|}{$\begin{array}{l}\text { Kraft paper and paper } \\
\text { board }\end{array}$} & 25 & $* *$ & & $*$ & * & & \\
\hline
\end{tabular}


Table 3. Substances contributing to each of the major categories of pollution hazard in the pulp and paper industry (from Poole et al., 1978, and Walden, 1976)

\begin{tabular}{|c|c|}
\hline Pollution hazard & Substances contributing to hazard \\
\hline Suspended solids & Fibre; bark residue; ash; lime; clay \\
\hline Dissolved organic substances & Lignins; carbohydrates; organic acids; alcohols \\
\hline Toxicity & $\begin{array}{l}\text { Resin acids; chlorinated lignins; chlorinated resin acids, phe- } \\
\text { nolics etc; unsaturated fatty acids; diterpene alcohols; juvabi- } \\
\text { ones; lignin degradation products e.g. lignosulphonates; fun- } \\
\text { gicides e. g. chlorinated hydrocarbon mixes, mercuric and } \\
\text { zinc compounds etc. }\end{array}$ \\
\hline Colour & Lignin derivatives; paper dyes and fibres \\
\hline
\end{tabular}

\section{TOXICITY PROBLEMS}

\section{Direct toxicity}

Table 3 lists the wide range of potentially toxic compounds which may be present in pulp and paper mill effluents. These are largely organic compounds derived from the dissolution of the raw material during processing. As such they are relatively easily oxidised in the marine environment (see below) and although in some circumstances they may have a high short-term toxicity they do not in general pose a serious accumulative threat. Most pulp and paper mill effluents do however contain small quantities of fungicides which are used to control mould growth at various stages in the process, most particularly during paper making. In the past mercuric compounds were often used for this purpose, but since the serious problems associated with the accumulation of mercuric compounds in the environment were recognised their use has been largely discontinued in favour of various types of polychlorinated phenolics (PCPs). Although such compounds have been shown to be significantly toxic to fish and various invertebrates (Davis \& Hoos, 1975; Poole et al. 1978) their concentration in discharged effluents is usually too low to have any significant environmental effect (Eloranta, 1975). The direct association of pulp mill effluent (PME) with other industrial effluents may produce toxicity problems in some areas. Cato et al. (1978) showed that a range of potentially toxic heavy metal ions was completely associated with the organic fraction of the sediments in an estuary south of Gothenberg polluted by both PME and other industrial wastes. Thus in any area receiving PME together with other industrial wastes containing heavy metals the association of the latter with the organics may facilitate their incorporation into biological food chains and thus create a possible environmental hazard.

The toxicity of the various organic compounds derived from cellulose extraction processes has been investigated in some detail. Galstoff et al. (1947) showed that concentrations of PME in excess of 2-3 parts per thousand has a significantly depressive effect on metabolic activity in the oyster. However they showed that the toxic elements in the effluent were rapidly oxidised on mixing with the receiving waters thereby reducing the toxicity. Concentrations of PME in the great majority of marine areas 
receiving discharges rarely exceed a few parts per million, e. g. Bagge (1969) reported that maximum concentrations in the surface waters of the Saltkällefjord (Sweden), which at that time received effluent from three pulp and paper mills at the head of the fjord, never exceeded 5 p.p.m. Whilst such concentrations would not have a directly toxic effect on adult organisms it is possible that larval growth and thus recolonisation might be affected. Woelke (1960) showed that serious abnormalities developed in oyster larvae subjected to concentrations of PME in excess of 2-3 p.p.m. Despite the possibility of such effects most investigations have concluded that direct toxicity effects are of negligible importance particularly in the marine environment when considering the overall impact of pulp and paper mill pollution (see Poole et al., 1978).

\section{Indirect (non-lethal) effects}

One further problem worthy of note in any discussion of toxicity hazards is the possibility of the occurrence of avoidance reactions in migrating fish coming into waters contaminated with PME. Elson (1974) analysed the records of salmon fished in the Miramichi river in Eastern Canada over a period of years. The NW branch of the river received effluent from a pulp mill, whereas the SW branch was unpolluted. Over a period of years during which effluent discharge to the NW Miramichi increased, the total catches of salmon in the SW branch increased progressively. When effluent control measures were introduced and the discharges to the NW branch were decreased the catches in that branch of the river recovered. Livingston (1975) found that several species of coastal estuarine fish avoided waters of an estuary in Florida polluted by PME although they were commoly present in an adjacent unpolluted estuary. However Wildish et al. (1976) found that avoidance reactions in herring were only stimulated by concentrations of PME in excess of $2.5 \mathrm{mg} / \mathrm{l}$, i. e. values much higher than those found in most environmental situations. Similarly Lewis \& Livingston (1977) showed that two species of estuarine fish in Florida had threshold avoidance levels of $0.06 \%$ PME. McLeese $(1970,1973)$ showed that lobsters (Homarus americanus) were unaffected even by PME concentrations up to $20 \%$, a concentration unlikely to be present in any marine situation. It seems therefore that behavioural responses to the presence of PME vary between different animal groups and species, with some estuarine species at least being relatively insensitive.

\section{DISCOLORATION OF WATER}

The effluent from many pulp and paper mills, in particular from kraft mills, is very dark, containing both dyes and lignin derivatives which may significantly reduce the transparency of the receiving waters. This results in much more serious environmental problems in fresh waters than in the sea, but in certain restricted marine areas, $i$. e. when effluent is discharged into the heads of narrow fjords, the reduction in water transparency may be sufficient to significantly reduce phytoplankton production. There appears to be no direct evidence of this occurring in any marine situation, but Harger et al. (1973) showed that there was a relationship between the diversity of species settling on the panels suspended at various distances from a source of PME In the Alberni Inlet on Vancouver Island and the transparency of the water. Zimmermann \& Livingston (1976) 
and Heck (1976) demonstrated that reduced water transparency in a Florida estuary polluted by PME resulted in a reduction in the area occupied by sea-grass beds and a concomitant increase in the estuarine area occupied by mud-flats. This in turn altered the species composition of the area and had the effect of considerably reducing the overall populations of epibenthic animals. Despite such evidence it must be assumed that in most marine situations dilution and dispersal of the effluent are sufficiently rapid to remove the possibility of light attenuation having any detrimental biological effect.

\section{ENVIRONMENTAL AND ECOSYSTEM EFFECTS ON MARINE SEDIMENTS}

The usual outcome of the addition of large quantities of organic material to a body of fresh water is eutrophication and subsequent deoxygenation of the bottom water. However in the marine enviroment such additions are generally made to areas where the volumes of the receiving waters are greater and the mixing and flushing characteristics more violent than is usual in inland situations. Thus in marine systems renewal of oxygen at the sediment/water interface is normally rapid and even a high BOD in the sediment rarely leads to a deoxygenated water column. Only in conditions of excessively high inputs in areas of low hydrodynamic energy input does stagnation and deoxygenation of the bottom water occur. Pearson (in press) has recently discussed in some detail the various factors leading to the establishment of such conditions in fjordic areas. Figure 1 gives a diagramatic summary of those factors which influence the development of stagnant conditions in marine basins. In the open sea conditions are rarely such as to encourage the onset of stagnation in bottom waters; however in upwelling areas eutrophication may occur, leading to a sufficiently high deposition of organic material at the sediment surface to create deoxygenation in the bottom waters (Sanders, 1969). High organic inputs lead to a sequential series of changes in the physical and chemical

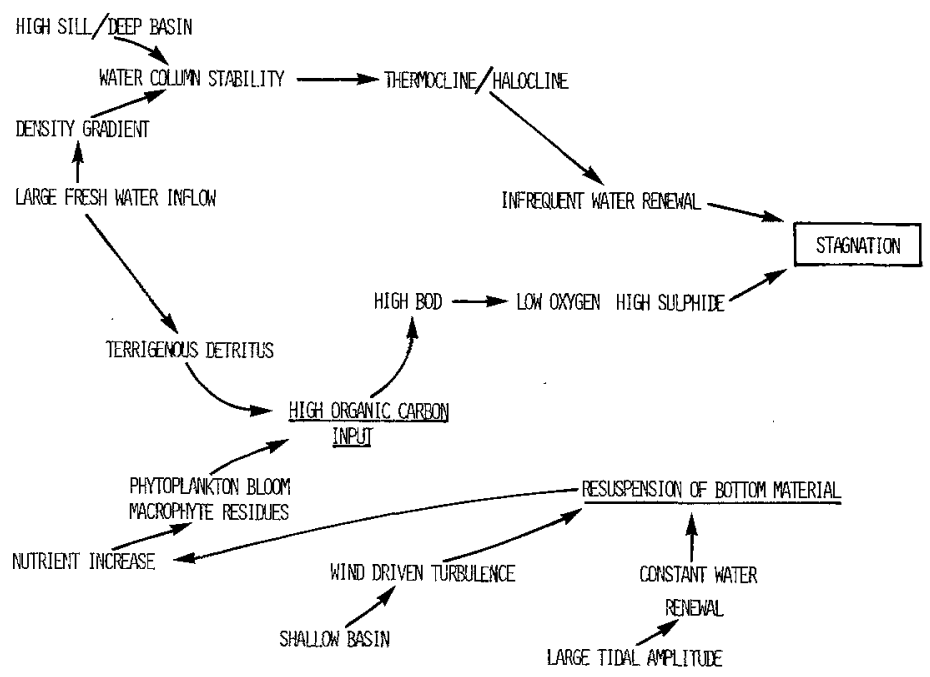

Fig. 1. Diagrammatic summary of the factors influencing the development of stagnant conditions in marine basins 
characteristics of the sediments and in their micro- and macrobiology. Such changes take place even beneath an oxygenated water column, but are accentuated by the occurrence of stagnation. Pulp and paper mill effluents contain large amounts of cellulose fibre which, when discharged to the marine environment, are sooner or later deposited at the sediment/water interface where microbial degradation takes place, thus providing the necessary high carbon input to initiate the changes described.

\section{DEGRADATION OF CELLULOSE FIBRE}

The breakdown of cellulose fibres in the marine environment has only recently been the subject of serious investigation and much remains to be learned of rates of degradation and the processes involved. Vance et al. (1979) have shown that cellulolysis of the secondary cell walls of bleached pulp fibre takes place in close proximity to bacterial cells, and that breakdown is enhanced by the mechanical damage to the outer cell walls which occurs during pulping. Moreover fractured cells appeared to be attacked more easily by invading bacteria. Similar observations were made by Latham et al. (1978) on the decomposition of plant cell material by rumen bacteria and it seems likely that bacterial cellulolytic action will follow the same pattern whatever the medium, although no other detailed studies in the marine environment have been made. The importance of mechanical abrasion of the fibres in enhancing bacterial breakdown is significant in two ways. Firstly it implies that unprocessed fibres will be degraded more slowly than those in which chemical and mechanical action has brought about some damage to the outer cell walls and secondly it suggests that any such abrasion which might occur within the sediments, e. $\mathrm{g}$. by mastication and/or ingestion by macrofauna, may have considerable influence on overall degradation rates. This latter possibility has not been substantiated by any critical investigations and the role of macrofauna in conditioning and controlling the microbiology and chemistry of the sedimentary ecosystem remains one of the least known and most intriguing aspects of benthic ecology (see below). A few studies have recently been carried out on the overall degradation rates of pulp fibre in both the water column and sediments which support the suggestion that processed fibres degrade more rapidly than unprocessed fibres. Hofsten \& Edberg (1972) showed that bleached sulphite pulp degraded more rapidly than dried pulp or cotton fibre, whereas lignin-containing mechanical pulp was hardly degraded at all over an experimental period of up to six months. Poole et al. (1978) showed that unbleached sulphite pulp degraded nearly four times as rapidly in unpolluted sediment as in anoxic sediment containing a high fibre content, but Hofsten \& Edberg suggested that degradation was as rapid under anaerobic conditions as in aerobic environments providing that nutrient levels were high and the conditions suitable for sustained growth of cellulolytic bacteria. Recent experiments by Pearson et al. (in preparation) have shown that under experimental conditions fibre degrades more rapidly in sediments containing high amounts of deposited fibre than in areas containing smaller amounts (Fig. 2) implying that the presence of active populations of cellulolytic bacteria in the sediments is a necessary prerequisite for the rapid breakdown of cellulose fibre. Under these circumstances anoxic conditions at the sediment/water interface had no effect on the degradation rate; indeed in confirmation of the observations of Hofsten \& Edberg (1972) the more rapid rates of degradation occurred under anoxic conditions when over $80 \%$ of the original fibre was degraded 


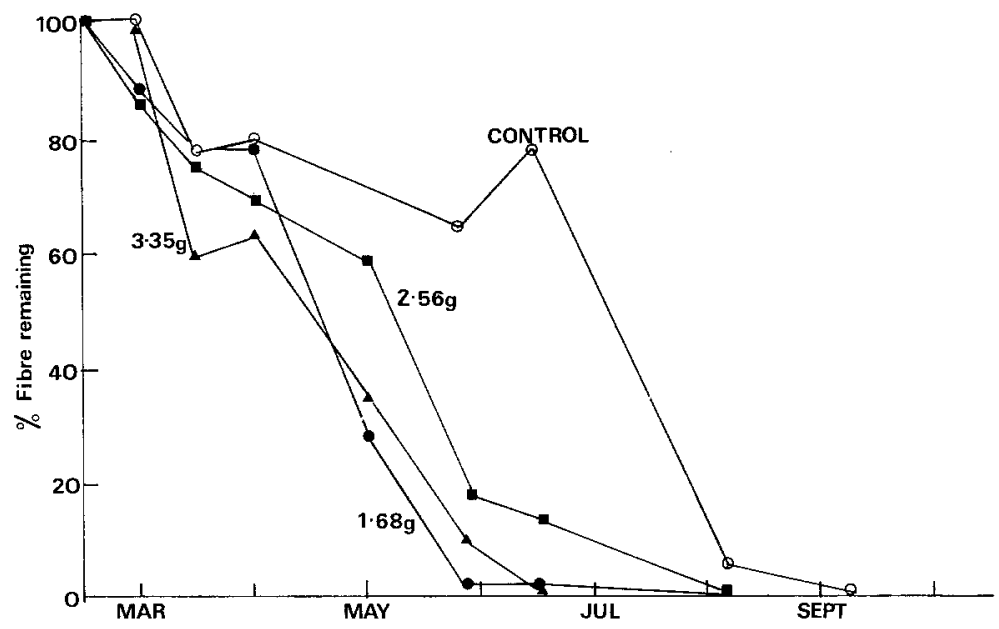

Fig. 2. Rate of degradation of cellulose fibre enclosed in nylon bags and placed in sediments receiving different daily rates of input of fibre (rates of daily input of fibre from 1.7 to $3.3 \mathrm{~g} \mathrm{dry}$ wt of fibre to tanks of sediment having a surface area of $0.3 \mathrm{~m}^{2}$ ) (from Pearson, Gibb \& Stanley, in preparation)

within 80 days of deposition in the sediments. In a sediment containing no previously deposited fibre and having an aerobic regime at the sediment/water interface only $30 \%$ of the original fibre had degraded after the same period.

\section{CHANGES IN SEDIMENTARY CHEMISTRY AND MICROBIOLOGY}

The breakdown of fibre in the sediments by bacterial action releases a variety of low molecular weight carbon sources which are then incorporated into the sedimentary ecosystem with concomitant impact on the chemical and biological regimes. An outline scheme for the probable chemical and microbiological processes involved is given in Figure 3 (from Stanley et al, 1978). This presents some details of pathways involved in the cycling of carbon and sulphur in the sediments and indicates part of the nitrogen cycle. Some points from this suggested model are worthy of closer examination before proceeding to a consideration of the overall effect of these processes on the sediment ecosystem.

\section{Carbon cycle}

The initial degradation of cellulose by cellulolytic bacteria results in the production of first cellobiose and then glucose. Under aerobic conditions glucose is usually rapidly metabolised by aerobic heterotrophic bacteria with the resultant evolution of carbon dioxide. In the absence of oxygen however acetate, succinate and other organic acids may also be formed as fermentation products of cellulose by anaerobic heterotrophs of various types and may accumulate to form considerable pools of metabolites in the interstitial water. Miller et al. (1979) showed that in the lower, totally anaerobic, levels of the sediments in an area of Loch Eil receiving high levels of cellulose fibre there was a 


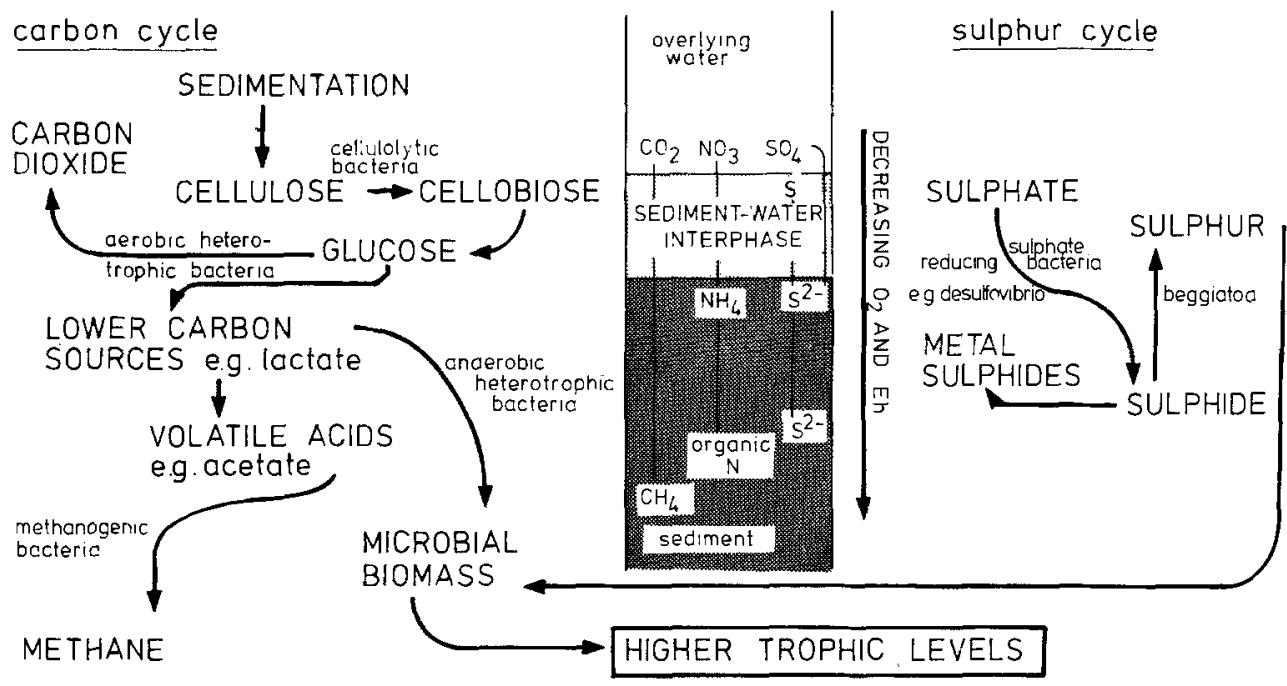

Fig. 3. Outline scheme for the probable chemical and microbiological processes involved in cellulose degradation in sediments (modified from Stanley et al., 1978)

considerable accumulation of propionate whereas in the surface layers in contact with an oxygenated water column considerable amounts of acetate were present. It was suggested that the levels of these substances were high enough to provide a potentially rich food source by direct adsorbtion for those higher invertebrates, e. g. polychaete worms, which were capable of assimilating material in that way. Under intense reducing conditions, i. e. when redox potentials in the sediment fall below $-150 \mathrm{mV}$, such lower carbon sources may form the substrate for methanogenic bacteria and their reduction may result in the production of significant quantities of methane. Under such extreme circumstances the evolution of methane may take place at the sediment surface (Stanley et al., 1978). In normal circumstances methane production would not occur in marine sediments except possibly at low levels in isolated "cells" associated with pockets of decaying material.

\section{Sulphur cycle and nitrogen fixation}

Marine sediments are rich in sulphate and sulphate reduction is one of the most important processes taking place in organically rich areas. Sulphate reducing bacteria such as Desulfovibrio probably utilize the low molecular weight organic acids produced through cellulolysis in anaerobic areas producing sulphides; indeed Vosjan (1974) and Leftley (in preparation) have shown that the rate of sulphate reduction in anaerobic sediments is markedly increased by addition of lactate, suggesting that the process is carbon limited rather than sulphate limited. The sulphides produced in turn can then be oxidised by filamentous bacteria such as Beggiatoa which develops extensively at the sediment/water interface in view of its requirement for both sulphur and oxygen. Thus it 
appears in areas where sulphide produced from anoxic sediment diffuses to a surface overlain by an oxygenated water column (Jørgensen, 1977). Mats of intermingled fibre and Beggiatoa are characteristic of the surface of sediments subjected to high inputs of pulp and paper mill wastes (Stanley et al., 1978) and other large natural inputs of organic material, e. g. Gallardo (1977), Spies \& Davis (1979). The accumulation of free sulphide in anoxic sediments is typical of areas subject to high organic inputs. Under stagnant conditions the lower levels of the overlying water column may become saturated with sulphide following the utilization of all the oxygen. When this occurs renewal of the bottom water is necessary to restore an aerobic condition. Desulfovibrio may also be responsible for significant levels of nitrogen fixation in anaerobic sediments. Blake \& Leftley (1977) showed that significant numbers of such bacteria were present in anaerobic sediments in Loch Eil and Loch Etive where detectable nitrogen fixation was taking place; moreover addition of lactate stimulated the rate of fixation after a lag period, again implying that such reactions may be carbon limited.

The reduction of nitrate, resulting initially in the production of ammonia also takes place in the upper anaerobic levels of the sediment. Nitrate is the preferred alternative electron acceptor in the absence of oxygen (see Whitfield, 1971) and in anoxic sediments ammonia may accumulate in significant quantities (Fig. 4) and diffuse into the overlying water column in stagnant conditions.

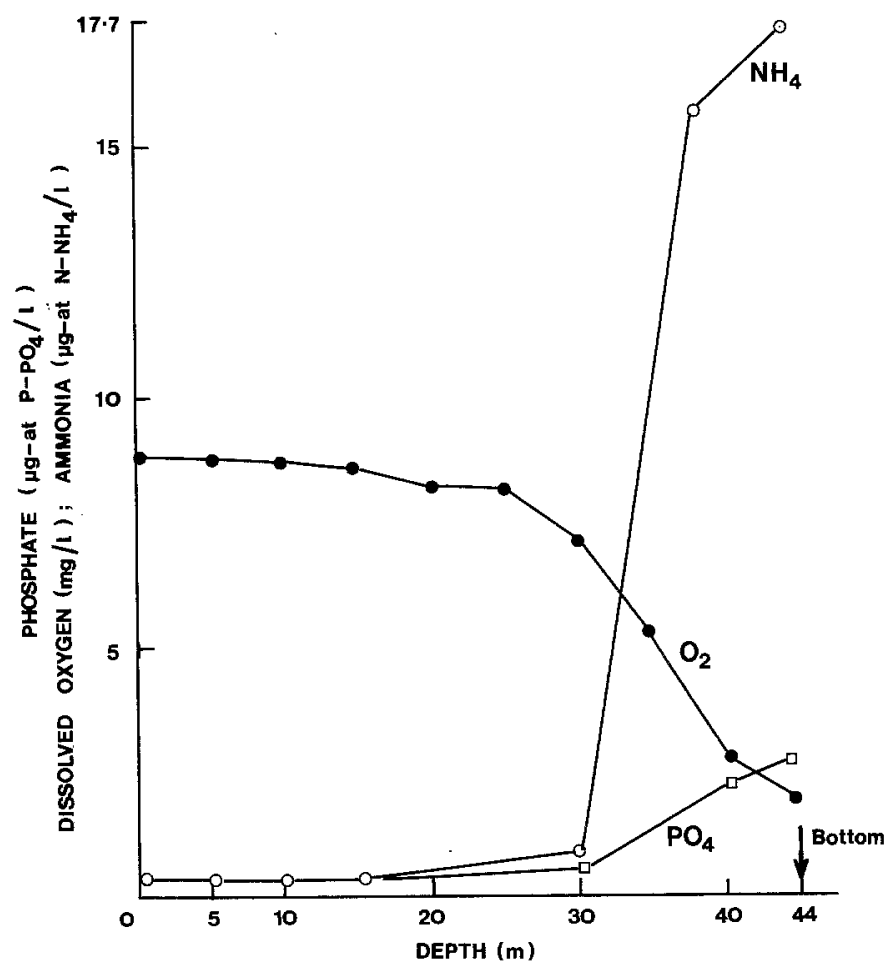

Fig. 4. Variation in the levels of oxygen, phosphate and ammonia down the water column in the inner basin of Sullom Voe, Shetland, during a period of stagnation, when significant levels of ammonia were found to have accumulated in the bottom waters (from Stanley et al., in press) 


\section{Overall effect on the sedimentary ecosystem}

The various processes described above occur simultaneously, are both interactive and interdependent and have a controlling influence on the macrobiology of the sediments. The changes in sedimentary chemical and physical conditions which occur as organic input is increased may be both summarized and exemplified by the accompanying changes in redox conditions. In a normal marine sediment, oxidised at the sediment/ water interface, redox potentials are positive and the presence of ferric oxides imparts a yellow/orange colour to the sediments. At progressively lower levels in the sediment the redox potentials become increasingly negative, free oxygen is fully utilized, and free sulphides appear; ferric compounds are reduced to ferrous, nitrates to nitrite and ammonia and partially reduced organic intermediates appear. These changes result in a colour change from yellow through grey to black in the sulphide zone. The overall effect of increasing the input of organic material is to bring all these latter changes to the sediment/water interface creating a black, reduced surface characterized by negative redox potentials. Pearson \& Stanley (1979) have shown that change in sedimentary redox potentials can be a useful indicator of the extent of pollution caused by pulp and paper mill effluent (see below). The essential interrelationships of these various changes and their influence on the macrobiology of the sediments are illustrated in Figure 5; they are

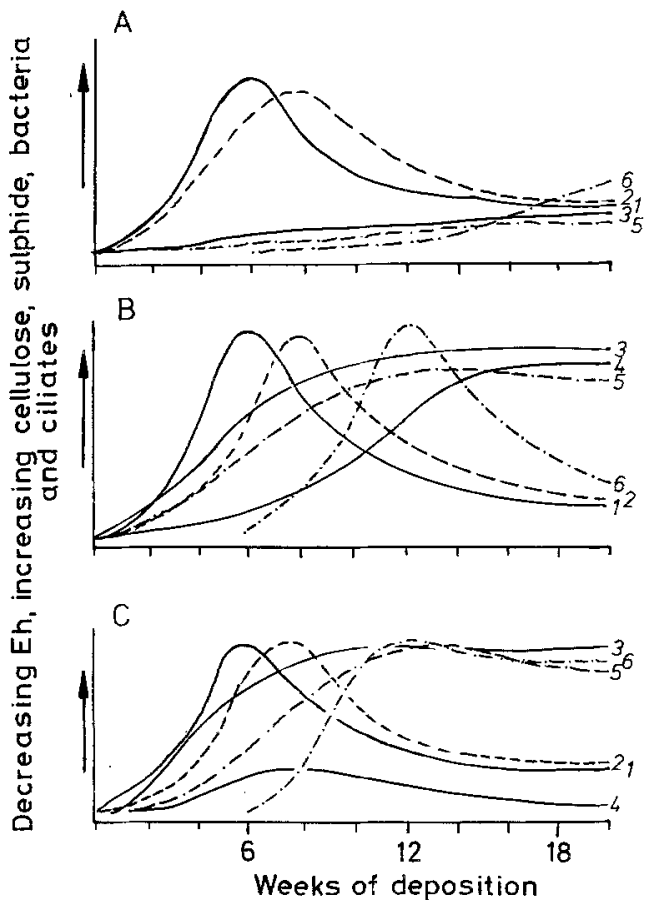

Fig. 5. Changes in several chemical and microbiological variables in artificial sediment systems subjected to differing inputs of cellulose fibre and variable water flows over the sediment surface. (A) Low rate of cellulose deposition. (B) High rate of cellulose deposition with low water flow. (C) High rate of cellulose deposition with high water flow. (1) Cellulose level in sediments. (2) Numbers of cellulolytic bacteria. (3) Redox potential (Eh). (4) Sulphide level. (5) Numbers of sulphate reducing bacteria. (6) Total numbers of ciliates 
based on information drawn from a series of laboratory experiments designed to assess the effect of flow rate over the sediment surface on cellulose breakdown under conditions of high and low deposition. When cellulose input to the sediment was maintained at a low level there was an initial accumulation of cellulose in the sediments followed after some two to three weeks by a build-up of cellulose degrading bacteria. Both cellulose and bacterial levels then declined to a relatively low level. After some ten weeks redox levels in the sediments had decreased marginally and the amount of sulphide and the numbers of sulphide reducing bacteria had increased slightly. The numbers of ciliates remained low for the first eight weeks of the experiment but increased somewhat in the subsequent two weeks. Under conditions of high cellulose deposition with a low water flow rate over the sediment surface the initial build up of cellulose and cellulolytic bacteria followed by their later decline was repeated but there was a relatively rapid fall in redox (Eh) values accompanied by a build-up of sulphate reducing bacteria. The sulphide level in the sediments rose slowly at first, but after the first month it increased rapidly to reach a peak during the second month of the experiments. This accumulation of sulphide coincided with a decline in the ciliate populations which had reached very high levels between the fourth and sixth weeks of the experiment. When a high rate of cellulose deposition was combined with a high flow rate, Eh levels rapidly declined but sulphide did not accumulate in the sediments, and the ciliate populations built up rapidly and thereafter maintained high populations. The other variables followed the same pattern as before.

These experiments were necessarily performed on a sediment devoid of macrofaunal invertebrates for the sake of simplicity and control. However it is probable that macrofauna would react to the chemical and microbiological changes in a similar manner to the reactions of the ciliate populations although on a longer time scale. Support for this contention may be found in a series of observations made on chemical, and micro- and macrobiological changes in the sediments of Loch Eil in relation to varying cellulose input briefly reported by Stanley et al. (1978). Measurements were made of the redox potential at $4 \mathrm{~cm}$ depth and the sulphide level in the sediment together with the numbers of aerobic cellulose digesting bacteria, of ciliates and of macrofaunal invertebrates. The changes in these variables over a twelve month period are shown in Figure 6. This shows that a considerable rise in the input of suspended solid material to the loch which occurred in early February 1976 was followed in March by a decrease in the redox potential and increases in the sulphide level, numbers of cellulolytic bacteria and ciliates. The monthly sampling interval between these field observations precluded the possibility of observing any sequential pattern to these reactions other than their obvious relationship to the change in input levels. However it did allow an insight into the timing of the related change in the numbers of macrofauna. These started to increase in March at the same time as the other sedimentary and microfaunal changes, but continued to increase during the ensuing two months while the bacterial numbers and ciliates decreased to their former levels. The species of macrofauna concerned were predominantly small detritivorous polychaetes probably feeding largely on bacteria; thus their population growth is apparently linked to the changes observed in the bacterial populations of the sediments.

The series of interdependent changes in the chemical and biological status of the sediments just described have been summarized by Poole et al. (1978) as a concept of the 


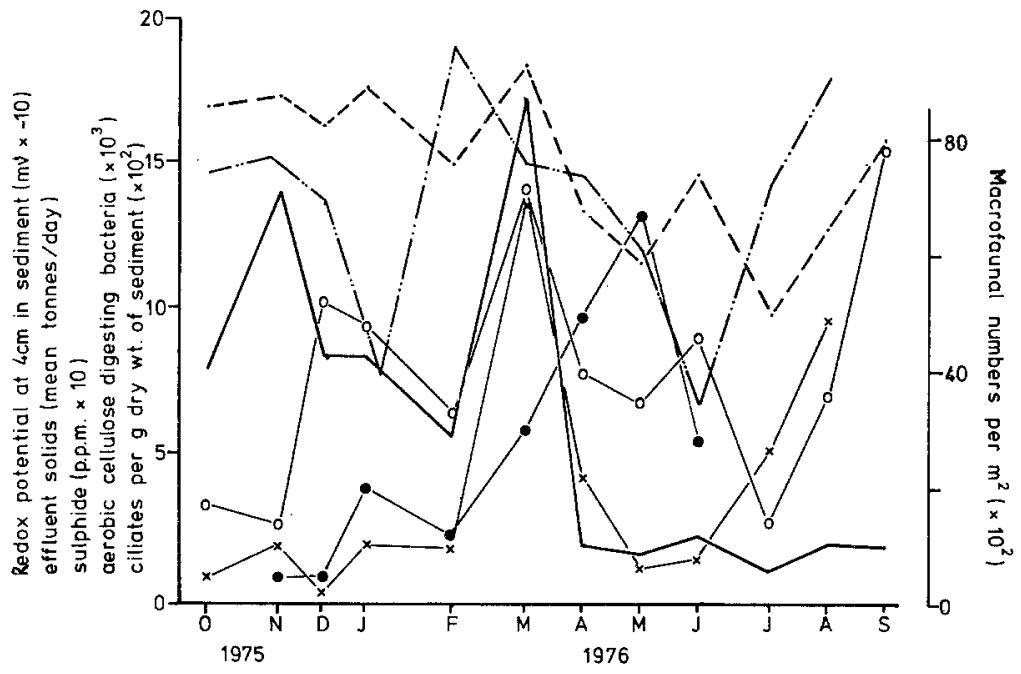

Fig. 6. The relationship between changes in organic input and chemical, microbiological and faunal properties of the sediments in an area of Loch Eil over a one year period. A sharp decline in redox potentials and peaks in sulphide concentration and bacterial and ciliate numbers were recorded in the month following a particularly high period of cellulose fibre input, followed some two months later by a peak in macrofaunal numbers. - - redox potential; $\ldots$. - effluent solids discharged to the loch; - sulphide; $\mathrm{x}-\mathrm{x}$ aerobic cellulose - digesting bacteria; $\bigcirc-O$ ciliates; $-\bullet$ macrofaunal numbers (modified from Stanley et al., 1978)

stabilization of organic matter derived from a point source of pollution. An initial decline in dissolved oxygen and autotrophic biomass at the point of input is accompanied by the elimination of macrofauna. The immediate rise in carbon levels is followed by an increase in heterotrophic biomass. As distance from the source increases bacterial biomass declines as macrofaunal numbers again build up and dissolved oxygen recovers to its former level.

\section{CHANGES IN BENTHIC MACROFAUNA}

The changes in the chemical and microbiological condition of marine sediments subjected to organic inputs from pulp and paper mill effluents are complex and take place fairly rapidly following effluent input as is evident from the information discussed above. Moreover methods for assessing such variables may be time consuming and technically difficult (see below). In contrast concomitant population changes in the benthic macrofauna take place over a longer time scale and may be regarded as integrating indicators of the general trends in chemical and microbiological change in the sediments over fairly extended time periods. Thus a spot assessment of macrobenthic community structure and population levels can be used to estimate the overall accumulative effect of PME on the marine environment in any area. A good example of the utility of such general surveys is found in Landner et al. (1977) who surveyed the benthic macrofaunal populations of a series of east coast bays and estuaries in Sweden which were subjected to effluent discharges from both pulp and paper mills and a 
variety of other pollutant sources. They showed a progressive reduction in number of species, abundance and biomass of macrofauna as the effluent discharge points were approached in all the areas surveyed. Whilst single surveys of this type in an area are useful in indicating the more obvious effects of effluent discharge repeated surveys over a period of time are desirable if any information is to be obtained about the effect of variations in effluent input and the interactions between such induced disturbance and natural environmental variability. Such long-term studies involving time-series sampling are expensive and thus relatively rarely carried out but two fully documented and relatively comprehensive surveys of this type have been undertaken in Loch Linnhe/ Loch Eil in Scotland (Pearson 1970, 1971a, b, 1972, 1975, in press) and in the Gullmar fjord in Sweden (Leppäkoski, 1968, 1975; Bagge, 1969; Rosenberg, 1971, 1972, 1973, $1974,1976)$. In the former area changes in the macrobenthos were assessed in the years following the introduction of PME into the loch system. In the latter macrobenthic population changes were followed in the aftermath of the closure of the pulp mills which had discharged to the head of the fjord over a period of years. The general conclusions from these two studies allowed a detailed assessment of the characteristic features of macrobenthic succession caused by organic enrichment which was described in Pearson \& Rosenberg $(1976,1978)$. The major course of such successions was summarized diagramatically (Fig. 7) showing change along a gradient of increasing enrichment from pulp fibre inputs. Thus the complex biologically structured communities of the benthos normally found in the silty sediments of such fjords when the organic input level is low, consisting of a diverse fauna drawn from a wide variety of phyla and encompassing a large range in physical size, are progressively reduced in physical, structural and genetic diversity to simple populations consisting of large numbers of a few small, resistant annelid species before even these opportunists are eliminated with the onset of total sedimentary anoxia beneath a blanket of deposited fibre. Such gradients of faunal change may be related either to a temporal or a spatial scale. In the Gullmarfjord the

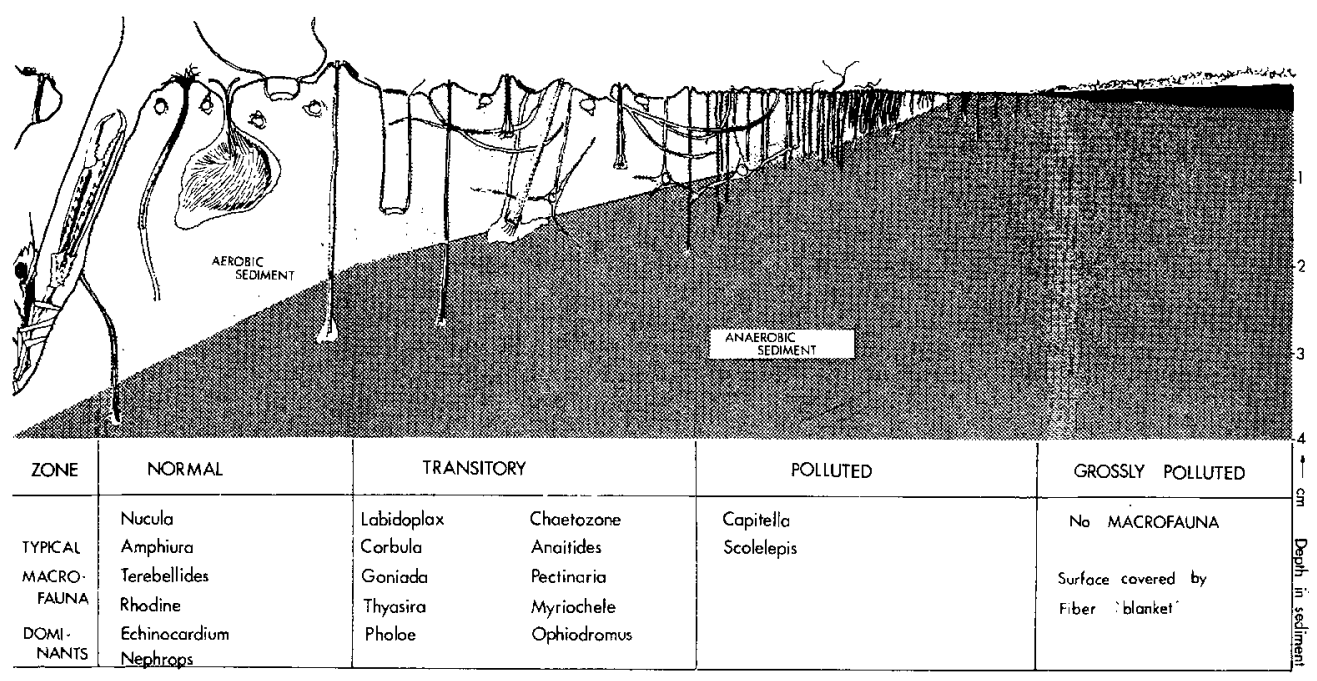

Fig. 7. Diagram of changes in fauna and sediment structure along a gradient of increasing organic enrichment by pulp fibre (from Pearson \& Rosenberg, 1976) 
early surveys by Bagge and Leppäkoski showed the distribution of fauna to be related sequentially down the fjord to the inputs of PME at the head of the fjord. Later Rosenberg demonstrated that recovery of the fauna at stations in the upper part of the fjord following cessation of PME input followed a similar pattern in time to the spatial pattern established down the fjord. Thus the stations originally most severely affected passed through the various stages along the succession gradient and eventually achieved the relatively stable and diverse biologically controlled populations which had always existed at the outer end of the Saltkällefjord beyond the influence of the effluent inputs (Fig. 8).
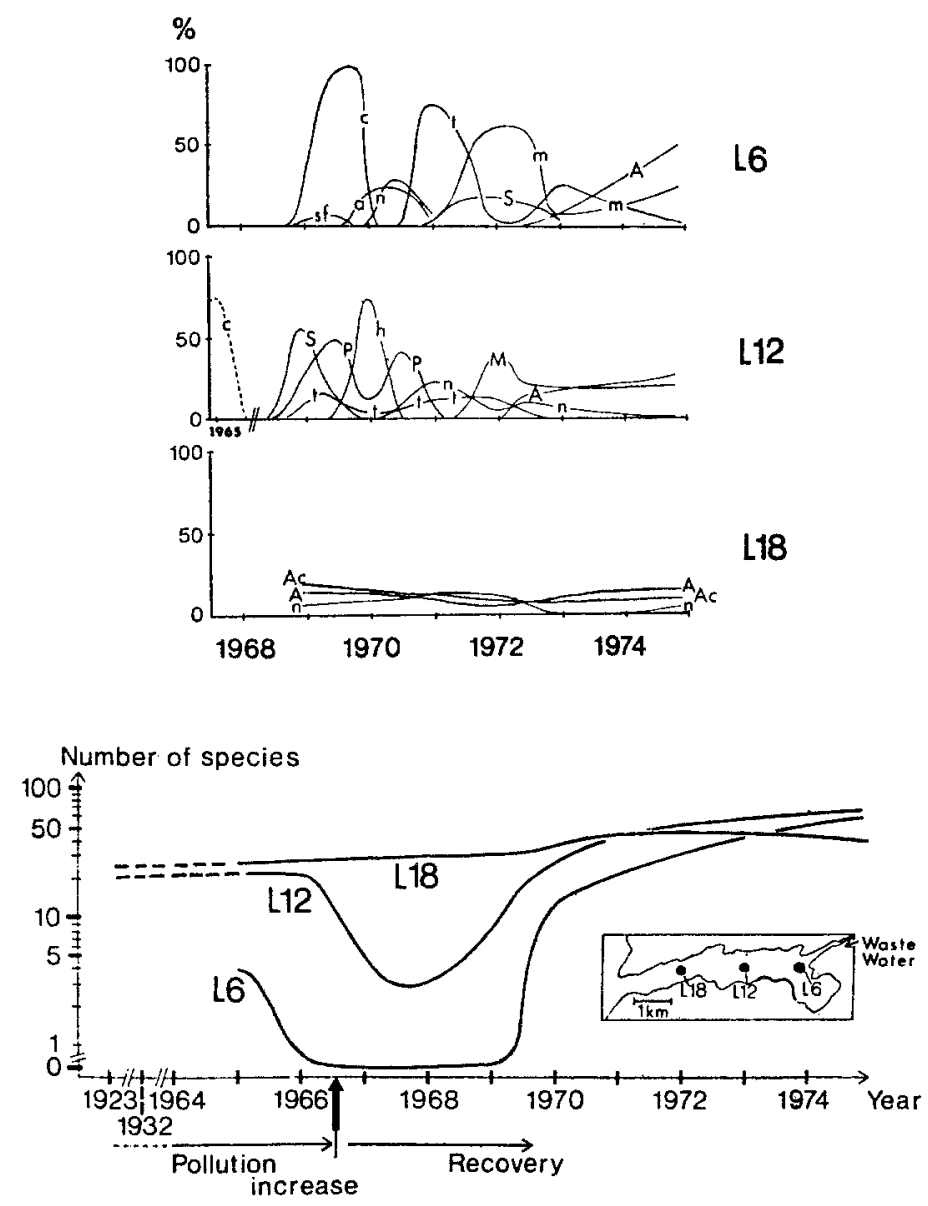

Fig. 8. Recovery of the benthic macrofauna in the Saltkällefjord following pollution abatement. The most polluted area, station L6, showed the greatest change in species numbers and the most vigorous population changes during recovery, but after some 6 years the community there, and at the intervening stations, approximated that at L18, a station at the mouth of the fjord some $5 \mathrm{~km}$ from the discharge point, which had shown relatively stable community structure throughout the period (from Rosenberg, 1976). c, Capitella capitata; sf, Scolelepis fuliginosa; a, Abra alba; n, Abra nitida; $\mathrm{t}$, Thyasira spp.; S, Scalibregma inflatum; m, Mysella bidentata; A, Amphuira filiformis; $\mathrm{H}$, Heteromastus filiformis; M, Myriochele oculata; P, Polyphysia crassa; Ac, Amphiura chiajei 
In Loch Eil similar changes were observed proceeding in the reverse direction as the effect of the introduction of PME progressively reduced the diversity of the fauna over a period of years in those areas of the loch where the majority of the discharged fibre was deposited. As the fauna in those areas became less diverse the populations of the various small annelid species which then came to dominate the benthos fluctuated more rapidly, and large changes in both total numbers and in species composition occurred from month to month. In areas where the effect of the effluent was less pronounced population fluctuations were less violent and changes in dominant species, which were drawn from much longer lived and more varied faunal groups including molluscs and echinoderms as well as annelids, tended to take place over a year or more.

Odum (1969) drew up a comprehensive list of the trends to be expected during the development of such ecological successions from the early developmental stages to the final mature communities: In this context the early stages are equivalent to the impoverished communities found in areas subjected to high effluent inputs. Such communities are generally of low diversity, poorly organised and are composed of small, unspecialized rapidly breeding species, whereas the mature communities show the opposite of all these trends. Benthic communities subjected to effluent input conform to most of these characteristic trends (Pearson \& Rosenberg, 1978). Thus in Loch Eil the size of the animals making up the communities in the deep basin gradually became smaller as the impact of effluent input developed over the years (Fig. 9). The decrease in the structural level of organisation of the communities as organic input increases involves the elimination of the larger animals which maintain complex burrow structures or extensive surface tube structures for filter-feeding purposes, and their replacement by small deposit feeders which maintain only simple, if any tube structures in the sediments. This change may involve a certain degree of what Rhoads \& Young (1970) termed trophic group amensalism, i. e. the exclusion of filter-feeding animals by the activities of deposit feeders through disturbing the sediments and clogging filter-feeding mecha-

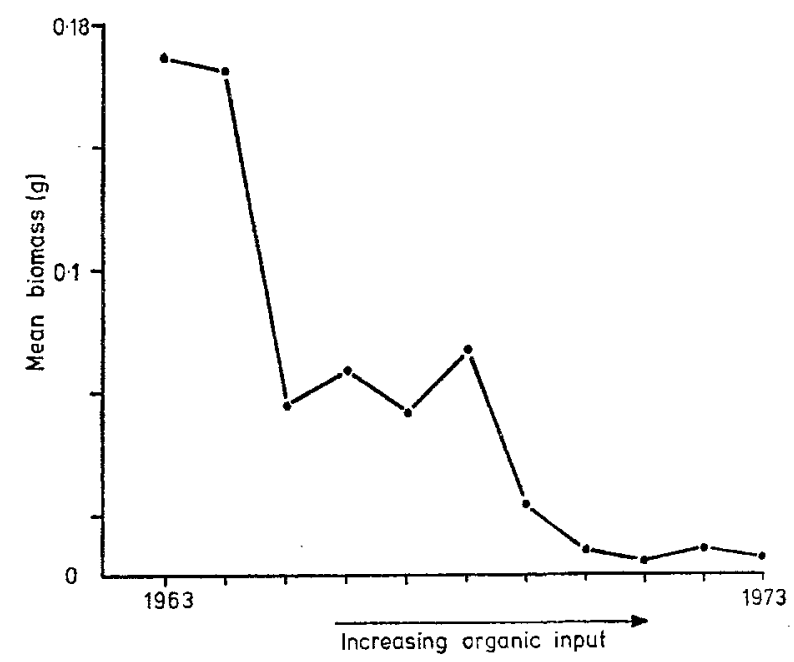

Fig. 9. The decrease in size over a ten year period of animals found in an area of Loch Eil subject to increasing organic input (from Pearson \& Rosenberg, 1978) 
nisms with resuspended particles. However such biological interactions are probably less important than the combined effects of the chemical and physical changes induced in the sediments by the increasing organic input. This results in a decrease in the width of the aerobic layer, a phenomenon which is intensified by the elimination of the larger burrowing and tube-building species which create a complex three-dimensional mosaic of aerobic and anaerobic patches in the sediment.

Recent work by Aller \& Yingst (1978) has indicated the complexity of the microclimates produced within the sedimentary structures created by the larger invertebrates. Tubes and burrows are lined with an aerobic layer of mucous sediment surrounded by increasingly anaerobic material; they thus contain complex redox gradients which are the sites for active and rapid decomposition of organic material. As such "structural" species are removed by the more severe chemical conditions imposed by increasing organic inputs then the structural complexity of the sediments is reduced and the redox

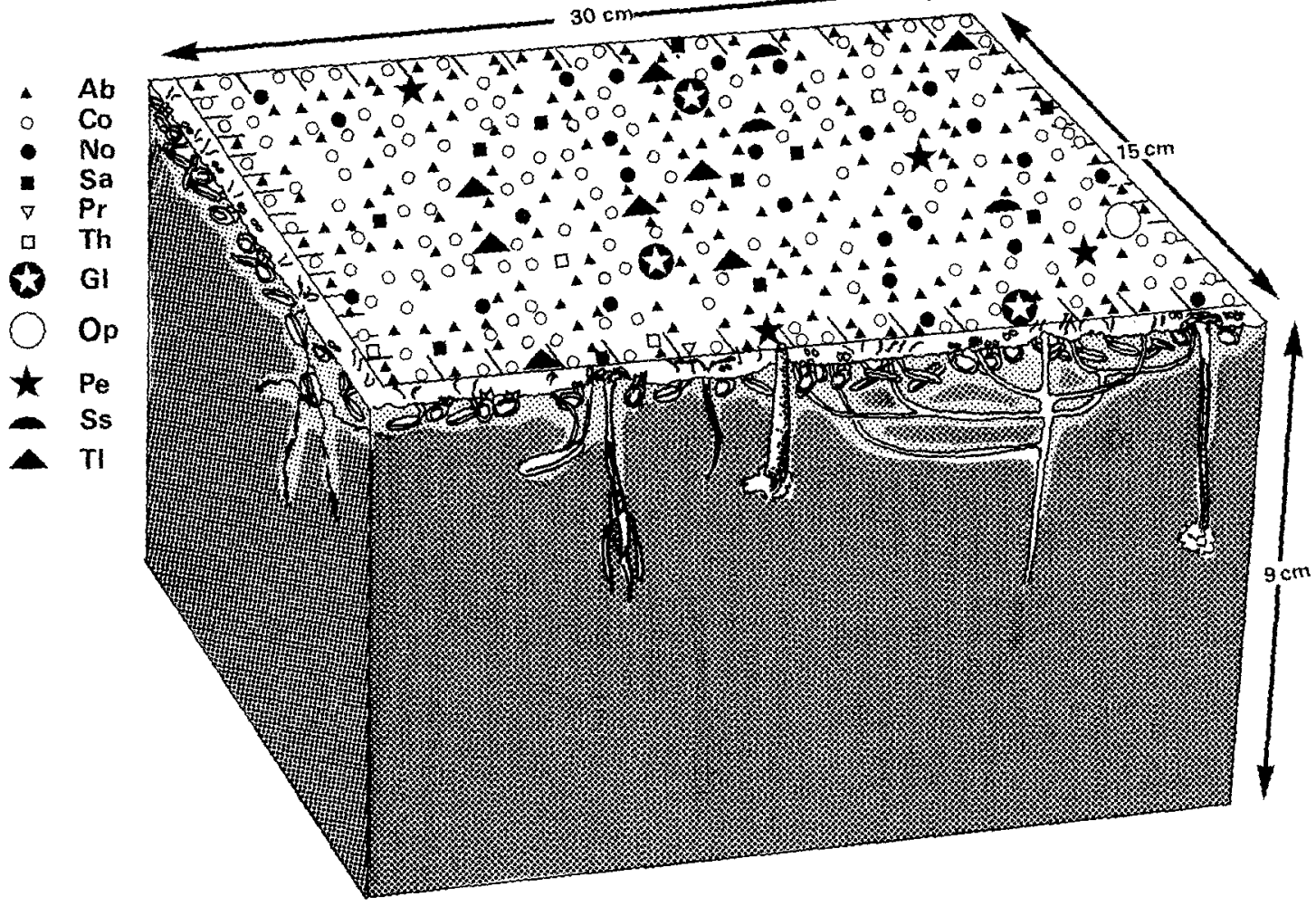

Fig. 10. Diagram representing the community structure and density of animals inhabiting $0.05 \mathrm{~m}^{2}$ of sediment in an area with low current speeds and relatively high organic inputs, where the fauna is dominated by small deposit feeding species such as the lamellibranch Abra and the annelids Prionospio concentrated at the surface layers of a largely anoxic sediment column (from Pearson, in press, b). Key: Light shading, oxygenated sediment. Dark shading, anoxic sediment. Ab Abra alba, Co Corbula gibba, No Notomastus latericeus, Sa Scalibregma inflatum, Pr Prionospio spp., Th Thyasira spp. Gl Glycera alba, Op Ophiodromus flexuosus, Pe Pectenaria koreni, Ss Spisula elliptica, Tl Tellina fabula 
gradients within the sediments become more uniformly orientated to the sediment/water interface. This will inevitably have the effect of reducing the total sediment area subject to fluctuating anaerobic/aerobic conditions and thus may reduce the overall rate of organic degradation within the sediments, leading to a further accumulation of carbon and an intensification of reducing conditions.

Pearson \& Eleftheriou (in press) illustrated diagramatically the structural and population changes in benthic communities, in Sullom Voe in the Shetland Isles, subjected to differing current speeds and organic inputs to the sediment. Thus in an area subjected to low current speeds and high organic inputs the populations were dominated by large numbers of deposit feeders concentrated near the sediment surface of the largely anoxic sediment column (Fig. 10), whereas in an area of relatively low carbon input and high current speed a highly structured and diverse community composed of animals drawn from many trophic groups was present. Change in the general trophic status of benthic communities subjected to increasing inputs of organic material was illustrated in Pearson \& Rosenberg (1978) using data again from Loch Eil (Fig. 11). Thus as the organic input increased the numbers of carnivores and suspension feeders decreased and the numbers of detritivores and their dependent population of carnivores increased.

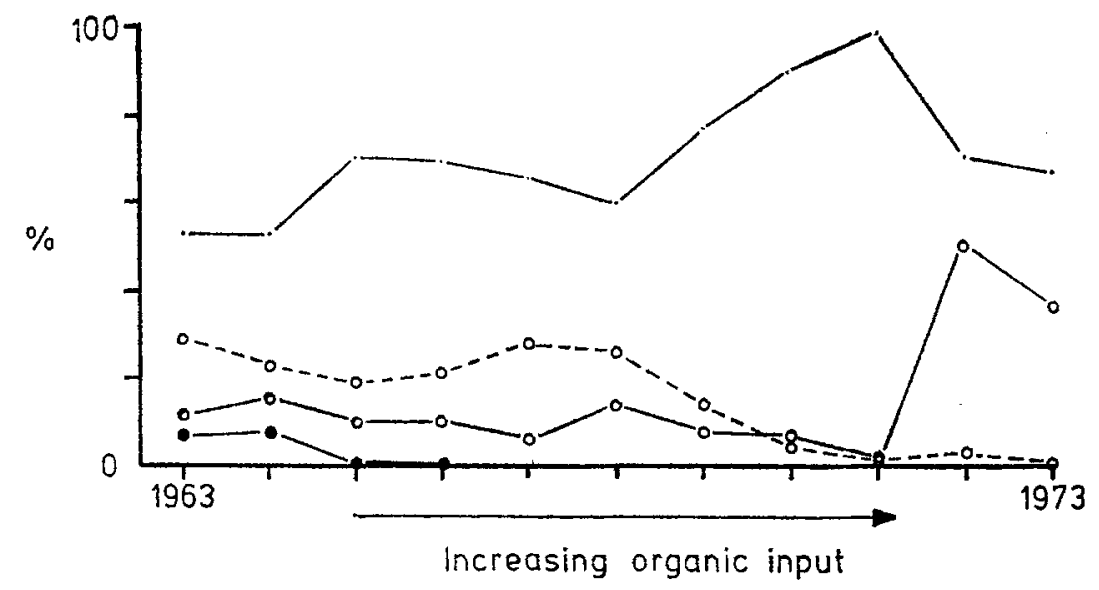

Fig. 11. Change in the percentage occurrence of different trophic groups at a station in Loch Eil subject to increasing inputs of pulp fibre over a ten-year period: - . - deposit-feeders; - o-carnivores; - - o-- suspension-feeders; - - omnivores (from Pearson \& Rosenberg, 1978)

\section{MONITORING THE EFFECTS OF PULP AND PAPER MILL POLLUTION}

The foregoing account of the main effects of the introduction of PME to a marine environment has touched briefly from time to time on the relative merits of the different types of environmental measurement described in assessing pollutant effects. It is thus relevant to consider in some more detail the advantages and disadvantages of the various analytical techniques available in order to recommend which, if any, are of use as general monitoring tools. Figure 12 shows a simplified scheme outlining the options open to the investigator of the effects of an environmental perturbation on a biological system. Thus there are three main investigatory options: (1) Environmental measure- 


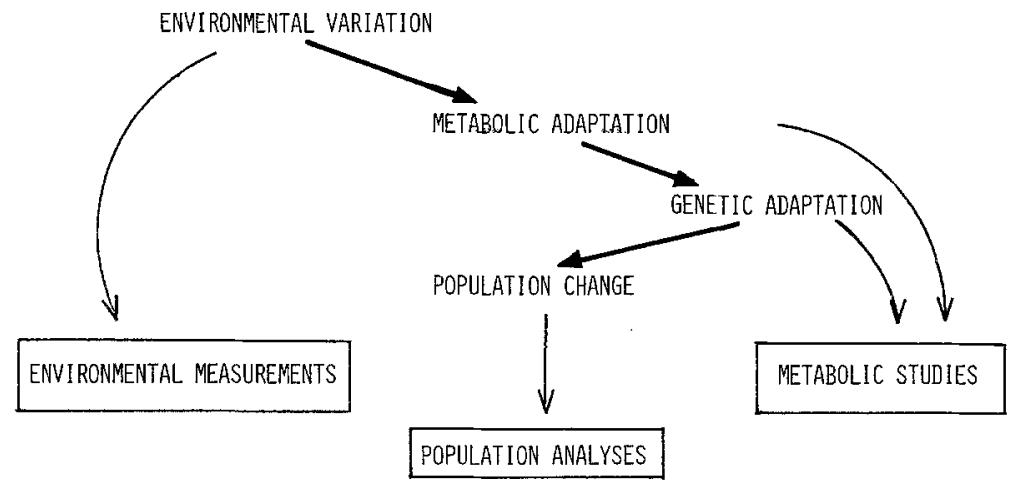

Fig. 12. Simplified scheme of the general stages of biological change in response to increasing levels of environmental stress, with the major investigatory options open at each stage

ments, i. e. direct or indirect measurements of the fluctuations in physical and chemical factors in the sediment or water column induced by the introduction of effluent to the

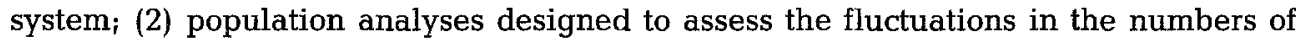
individual species and of communities in the face of environmental change; (3) metabolic studies of changes in the internal state of individual animals in response to the external stimulus. The utility of these various options is dependent both on their ease of measurement and on the response time of the measured change in relation to the induced environmental disturbance. Thus an examination of these two factors as they apply to the various techniques available gives some indication of the relative utility of each technique.

\section{Environmental measurements}

Analyses of changes in the physico-chemical condition of the sediments and water column are relatively easily performed and may cover a range of response time from hours or days in the case of measurements of e. g. temperature, salinity, oxygen, reducing condition (Eh) etc. to weeks or months when variables such as carbon, cellulose or lignin are measured. However the major drawback in the general use of such measurements is that they provide long- or short-term information on the degree of environmental change initiated by the input of an effluent but no indications of any of the biological changes that might be occurring. Thus in a balanced monitoring programme the measurement of such variables would be combined with some assessment of biological change at one level or another. Should it be possible to associate the degree of change in population levels in an area with a concomitant change in an environmental variable then measurement of the latter may allow a rapid estimate of the probable extent of population change to be expected. This approach has recently been taken by Pearson \& Stanley (1979) who have shown that changes in the redox potential in the sediments of some Scottish sea-lochs, which itself is directly related to the input levels of organic material to the sediments, can be used to predict the general degree of change in the benthic populations of the sediments (Fig. 13). Other variables can also be shown to vary in a predictable way in relation to population fluctuations, but the relative rapidity 


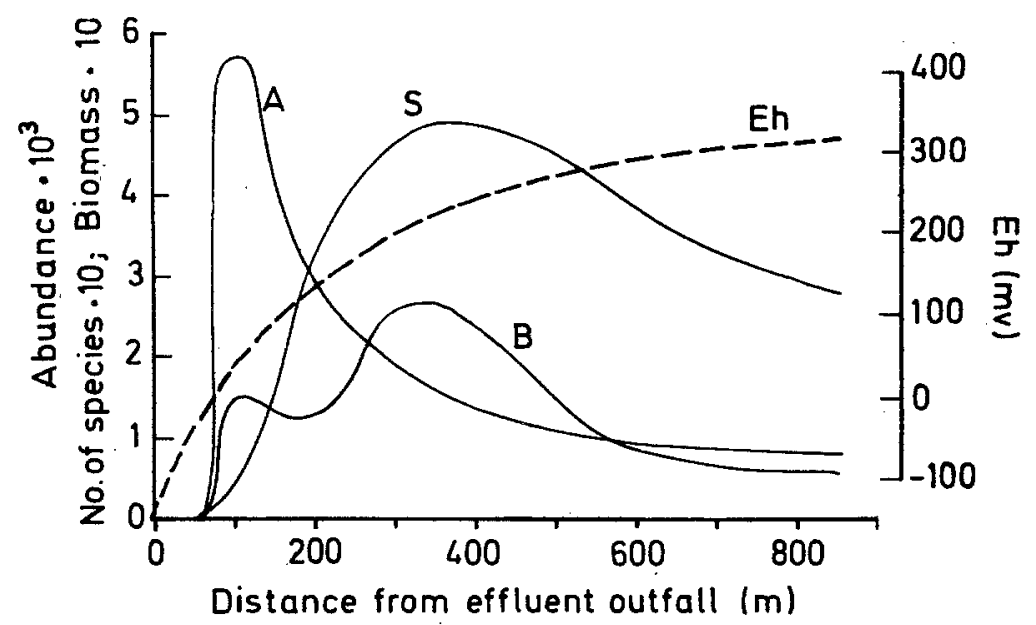

Fig. 13. SAB (species, abundance, biomass) curves along a gradient of decreasing sedimentary organic content compared with Eh values along the gradient. Faunal communities at any point on the gradient can be related to a predictable range of Eh values. S: number of species; A: total abundance; $\mathrm{B}$ : biomass $\left(\mathrm{g} \mathrm{m}^{-2}\right)$; - - Eh values at $40 \mathrm{~mm}$ depth in sediment (from Pearson \& Stanley, 1979)

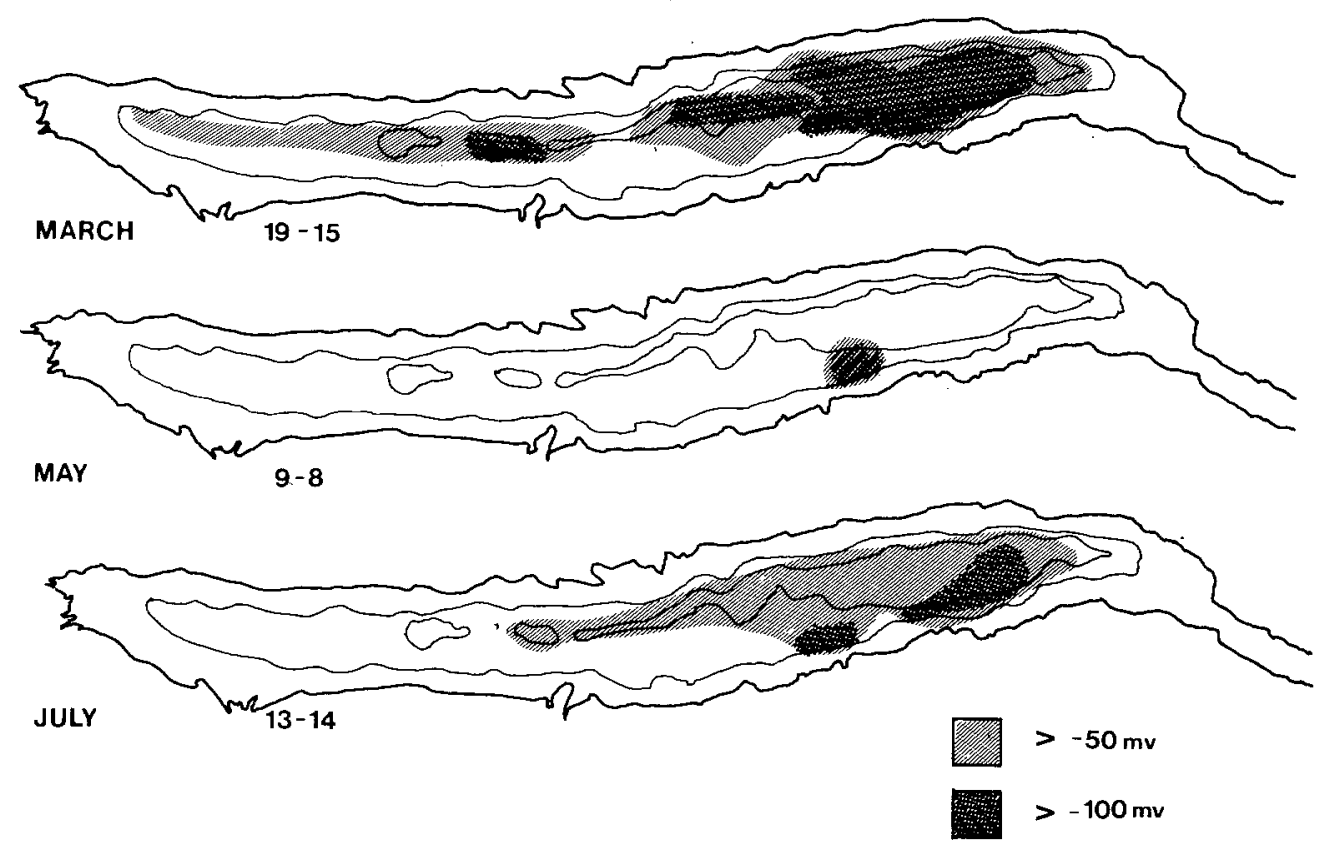

Fig. 14. Maps of Loch Eil (20 and $40 \mathrm{~m}$ depth contours marked), showing areas of low redox potential on three successive sampling occasions in 1977. Values under each map are mean daily tonnage of suspended solids in pulp mill effluent discharged to the loch for the preceding two months. Low redox values in March followed high effluent discharge levels in the preceding months. Low input levels in March and April were followed by a marked reduction in the area of highly reduced sediment but higher inputs in May and June resulted in an increase in the area again in July (from 
and ease with which redox levels can be measured in the sediment and their direct relevance to the living conditions of the fauna makes their measurement a preferred method for assessing the impact of additional organic inputs to marine sediments. The use of redox mapping techniques (Whitfield, 1969; Pearson \& Stanley, 1979) enables a rapid assessment of potential population changes over large areas to be made (Fig. 14).

\section{Population analyses}

Analysis of faunal populations in the sediments can encompass the full range of organisms from bacteria to the larger invertebrates. The response time of the various groups to an environmental perturbation varies widely, even within groups, but in general the longer response times are associated with the larger, longer lived species. Analysis of any faunal population involves relatively time consuming enumeration of one type of sample or another, usually combined with the necessity for expert identification of species. Thus there are no rapid and easy methods available for population analysis. It is therefore highly desirable to make an informed choice of which group should be analysed, based both on the response time of that particular group to disturbances caused by fluctuation in effluent input and to the relative ecological importance of the role of that particular group in the system being studied. Different faunal groups differ in their relative roles in the carbon and nutrient cycles in the sediments e. g. macrofauna may compose a large part of the biomass in an area but be less important than the meiofauna in the turnover of nutrients, breeding more slowly in general and having lower metabolic rates than the smaller species. An example of this type of differential role played by the various size groups of fauna in a sedimentary environment was provided by Fenchel (1969) in his studies of the fauna of a fine sand at $10 \mathrm{~m}$ depth in the Øresund. Although the macrofauna was completely dominant in terms of biomass the microfauna was responsible for forty percent of the total animal respiration, and of this the ciliates accounted for about $25 \%$. Although it is usually impossible to provide this type of detailed information in the majority of pollution assessment surveys, a selection of either bacterial, micro-, meio-, or macrofaunal populations as the major study group may be made on the basis of the general knowledge of their relative role in the particular environment being studied. The majority of surveys undertaken to assess the effects of PME have concentrated on macrofaunal changes, probably because both the study techniques and the taxonomy of that group are relatively well known (see e. g. Landner et al., 1977; Pearson \& Rosenberg, 1978; Poole et al., 1978). However recent work by Vance (1978) and Wyatt (1979) has shown that population changes in both bacteria and ciliate faunas can be linked to changes in effluent input and in certain circumstances are useful indicators of environmentally advisable input levels.

\section{Metabolic studies}

One of the major drawbacks associated with reliance on population analyses as a means of assessing the impact of a discharged effluent is the retrospective nature of the evidence collected, i. e. only after the community has adjusted to a perturbation which has had a lethal effect on at least some of the fauna previously present in the area can an effect be demonstrated. It is obviously more desirable to use some measure of demonstra- 
Table 4. Metabolic studies for assessing the impact of pulp mill effluents

\begin{tabular}{|lll|}
\hline Measured variable & Monitoring technique & $\begin{array}{l}\text { Response time to } \\
\text { environmental variation }\end{array}$ \\
\hline $\begin{array}{l}\text { Integrated physiological } \\
\text { response, e.g. energy, ba- } \\
\text { lance, growth efficiency }\end{array}$ & $\begin{array}{l}\text { Direct measurement of oxygen } \\
\text { consumption, food intake, assimi- } \\
\text { lation efficiency, excretion, etc. on } \\
\text { individual animal }\end{array}$ & Hours, days or weeks \\
Biochemical response & $\begin{array}{l}\text { Measurement of biochemical con- } \\
\text { stituents of individual animals or } \\
\text { tissues }\end{array}$ & \\
$\begin{array}{l}\text { e.g. Electron transfer sys- } \\
\text { tem activity, adenylate } \\
\text { energy charge, enzymatic } \\
\text { activity }\end{array}$ & $\begin{array}{l}\text { Measurement of ETS activity and } \\
\text { respiration rates; measurement of } \\
\text { ATP/ADP ratio; analysis of activi- } \\
\text { ties of key enzymes, e.g. PFK, CS, }\end{array}$ & \\
PK, etc. & \\
\hline
\end{tabular}

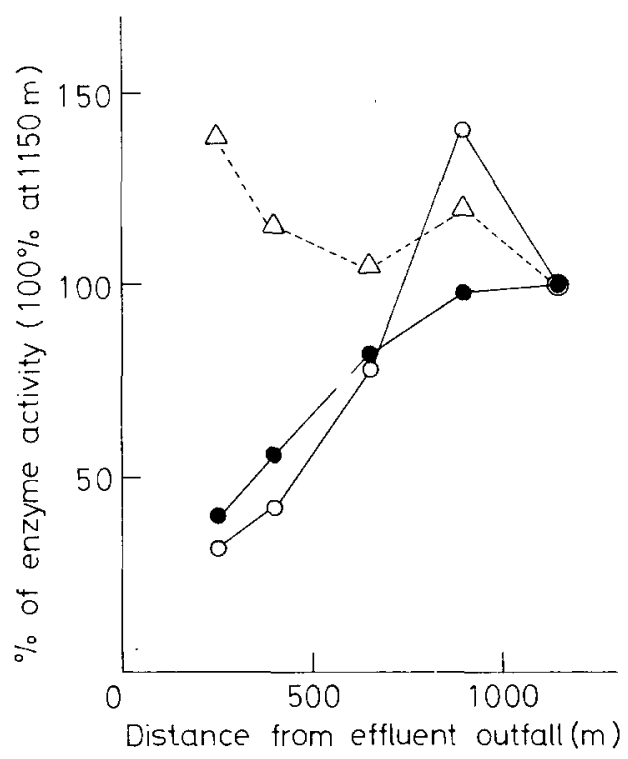

Fig. 15. Relation between distance from effluent outfall and activities of three enzymes associated with energy yielding metabolism in Glycera alba from Loch Creran (J. Blackstock, personal communication)

ble sub-lethal effects of the effluent on the fauna should any such measure be available. Various physiological and biochemical responses of individual animals to environmental stress have been assessed in this context in an endeavour to link a measurable response to an external variable, the more promising of which are listed in Table 4 . Very few of these have been used as yet to specifically identify responses to PME, other than change in enzymatic activity in some polychaete worms (see below), but in so far as all 
such measured internal responses are caused by the animals being subjected to external stress the exact nature of that stress becomes secondary. The metabolic responses studied have been either physiological studies of factors such as energy balance, growth efficiency etc., e. g. Bayne et al. (1976), Widdows (1978), or assessments of various types of biochemical change. The latter have included investigations of electron transfer system activity (Packard et al., 1974; Bamstedt, 1979), adenylate energy charge (Schöttler, 1978; Rainer et al., 1979) and various levels of enzymatic activity (Blackstock 1978, in press). The latter studies have been carried out to assess the effects of variation in the effluent input to Loch Eil on the activities of enzymes associated with energy yielding metabolism in a number of polychaete worms which have populations distributed in areas of the loch subjected to differing amounts of effluent input. It has been shown that the activities of a number of enzymes are progressively suppressed in animals drawn from areas approaching the effluent source (Fig. 15). It is possible that regular assessment of such enzymatic activities could provide the basis of a measurable sub-lethal response to effluent input levels. However much research and development work remains to be done before the measurement of such sub-lethal effects becomes a useful technical method for inclusion in routine monitoring surveys.

\section{CONCLUSIONS}

The foregoing account of the scale of pollution from cellulose industry wastes, their characteristic effects on the environment and ecology of marine areas to which they are discharged, and the methods by which such effects can be assessed suggests that given reasonable levels of control the discharge of such wastes to the marine environment need not pose a serious hazard. Should such discharges take place to areas with restricted water exchange then accumulation of carbon in the sediments may eventually cause deoxygenation of bottom waters and subsequent faunal elimination. However in areas where bottom water renewal is frequent the occurrence of such problems is unlikely and the additional carbon inputs from the effluent can increase the overall productivity of the system. Thus if the community changes in response to increasing carbon input can be confined to that part of the typical benthic succession where the total biomass and number of species are greatest (see Fig. 13) then it is possible that eventually commercial fisheries in the area could be enhanced. However in order to ensure that carbon inputs do not exceed the capacity of the system to absorb them some form of environmental monitoring of the effluent effects should be undertaken as part of the overall industrial programme. Given a baseline knowledge of the biology of the system into which the effluent is being discharged such a monitoring programme could be based on a relatively simple assessment of some key environmental variable e. $g$. the redox potential of the sediments, combined with an occasional analysis of the status of one of the major benthic population groups. Given this level of assessment any potentially hazardous environmental change can be rapidly analysed in relation to fluctuation in effluent input. In the relatively near future the monitoring of biochemical change in selected individual species from the area subjected to effluent input should provide early warning of any potentially detrimental effect stemming from a change in effluent input levels.

In this manner biologists may remain "watchful" rather than become alarmists. 
Acknowledgements. Parts of the information on the Loch Eil system discussed in this paper have been obtained as part of the Loch Eil project, a co-operative study involving the following personnel: from the Scottish Marine Biological Association, the author, S. O. Stanley, A. Edwards, J. Blackstock, P. Tett, J. Leftley, L. Solorzano, B. Grantham, D. Edelsten, I. Stanley, A. Lightfoot, N. Robertson, G. Duncan, J. Nuttall, N. Pascoe, C. Wyatt, I. Vance; from the Department of Biological Sciences, University of Dundee, D. Blake, C. M. Brown; from the Department of Civil Engineering, University of Strathclyde, G. Fleming, R. Walker. In carrying out the cellulose degradation studies in model sediment systems the invaluable work of A. Lightfoot, C. Wyatt and I. Vance is particularly acknowledged, as are the comments and suggestions of Dr. S. O. Stanley following a critical reading of the manuscript.

\section{LITERATURE CITED}

Aller, R. C. \& Yingst, J. Y. 1978. Biogeochemistry of tube dwellings: a study of the sedentary polychaete Amphitrite ornata (Leidy). - J. mar. Res. 36, 201-254.

Bagge, P., 1969. Effects of pollution on estuarine ecosystems. 1. Effects of effluents from wood processing industries on the hydrography, bottom and fauna of Saltkällefjord (W. Sweden). Merentutkimuslait julk. 228, 3-118.

Bamstedt, U., 1978. Seasonal variation in the respiratory rate and ETS activity of deep water zooplankton from the Swedish west coast. In: Cyclic phenomena in marine plants and animals. Ed. by E. Naylor \& R. G. Hartnoll. Pergamon Press, Oxford, 267-274.

Bayne, B. L., Livingstone, D. R., Moore, M. N. \& Widdows, J., 1976. A cytochemical and a biochemical index of stress in Mytilus edulis L. - Mar. Pollut. Bull. 7, 221-224.

Blackstock, J., 1978. Activities of some enzymes associated with energy yielding metabolism in Glycera alba (Müller) from three areas of Loch Eil. In: Physiology and behaviour of marine organisms. Ed. by D. S. McLusky \& A. J. Berry. Pergamon Press, Oxford, 11-20.

Blackstock, J. Estimation of activities of some enzymes associated with energy yielding metabolism in the marine polychaete worm Glycera alba (Müller) and application of the method to the study of organic pollution effect. - J. exp. mar. Biol. Ecol. (In press.)

Blake, D. \& Leftley, J. W., 1977. Studies on anaerobic nitrogen fixation in the sediments of two Scottish sealochs. In: Biology of benthic organisms. Ed. by B. F. Keegan, P. O. Ceidigh \& P. J. S. Boaden. Pergamon Press, Oxford, 79-84.

Cato, I., Olsson, I. \& Rosenberg, R., 1978. Sediments, meiofauna and macrofauna in the Askimsvik, (In Swedish with English summary). - Statens Naturv. PM 1046, 1-90. (Mimeo.)

Commission of the European Communities, 1974. Pollution of water by the pulp manufacturing industry in the E. E. C. - Techn. Rep. Environ. Consumer Protection Serv., 42 pp.

Conlan, K. E. \& Ellis, D. V., 1979. Effects of wood waste on sandbed benthos. - Mar. Pollut. Bull. 10, 262-267.

Davis, J. C. \& Hoos, R. A. W., 1975. Use of sodium pentachlorophenate and dehydroabietic acid as reference toxicants for salmonid bioassays. - J. Fish. Res. Bd Can. 32, 411-416.

Eloranta, V., 1975. Influence of some biocides employed in the wood-processing industry on growth of green algae. - Aqua fenn. 4, 21-28.

Elson, P. E., 1974. Impact of recent economic growth and industrial development on the ecology of Northwest Miramichi Atlantic salmon (Salmo salar). - J. Fish. Res. Bd Can. 31, 521-544.

Fenchel, T., 1969. The ecology of marine microbenthos. IV. Structure and function of the benthic ecosystem. Its chemical and physical factors and the microfauna communities with special reference to the ciliated Protozoa. - Ophelia 6, 1-182.

Gallardo, V. A., 1977. Large benthic microbial communities in sulphide biota under Peru-Chile subsurface counter current. - Nature, Lond. 268, 331-332.

Galstoff, P. S., Chipman, W. A., Engle, J. B. \& Calderwood, H. N., 1947. Ecological and physiological studies of the effect of sulphate pulp mill wastes on oysters in the York River, Virginia. - Fish. Bull. Fish Wildl. Serv. U. S. 51, 57-186.

Gehm, H., 1973. State-of-the-art review of pulp and paper waste treatment. - Environ. Protection Technol. Ser. Rep. EPA-R2-73-184.

Gray, J. S., 1979. Pollution induced changes in populations. - Phil. Trans. R. Soc. (B) 286, 545-561. 
Harger, J. R. E., Campbell, M. L., Ellison, R., Locke, W. P. \& Zwarych, W., 1973. An experimental investigation into the effects of pulp mill effluent on structure of biological communities in Alberni Inlet, British Columbia. Part 1 Subtidal communities. - Int. J. environ. Stud. 4, 269-282.

Heck, K. L., 1976. Community structure and the effects of pollution in sea-grass meadows and adjacent habitats. - Mar. Biol. 35, 345-352.

Hofsten, B. V. \& Edberg, N., 1972. Estimating the rate of degradation of cellulose fibres in water. Oikos 23, 29-34.

Hughes, T., 1970. Crow. From the life and songs of the crow. Faber \& Faber, London, 94 pp.

Jørgensen, B. B., 1977. Distribution of colorless sulfur bacteria (Beggiatoa spp.) in a coastal marine environment. - Mar. Biol. 41, 19-28.

Landner, L., Nilsson, J. \& Rosenberg, R., 1977. Assessment of industrial pollution by means of benthic macrofauna surveys along the Swedish Baltic coast. - Vatten 3, 324-379.

Latham, M. J., Brooker, B. E., Pettipher, G. L. \& Harris, P. J., 1978. Ruminococcus flavefaciens cell coat and adhesion to cotton cellulose and to cell walls in leaves of perennial ryegrass (Lolium perenne). - Appl, environ. Microbiol. 35, 156-165.

Leppäkoski, E., 1968. Some effects of pollution on the benthic environment of the Gullmarsfjord. Helgoländer wiss. Meeresunters. 17, 291-301.

Leppäkoski, E., 1975. Assessment of degree of pollution on the basis of macrozoobenthos in marine and brackish-water environments. - Acta Acad. åbo. (B) 35, 1-90.

Lewis, F. G. 111 \& Livingston, R. J., 1977. Avoidance of bleached kraft pulp mill effluent by pinfish (Lagodon rhomboides) and gulf killifish (Fundulus grandis). - J. Fish. Res. Bd Can. 34, 568-570.

Livingston, R. J., 1975. Impact of kraft pulp-mill effluents on estuarine and coastal fishes in Apalachee Bay, Florida, USA. - Mar. Biol. 32, 19-48.

McLeese, D. W., 1970. Behaviour of lobsters exposed to bleached kraft mill effluent. - J. Fish. Res. Bd Can. 27, 731-736.

McLeese, D. W., 1973. Response of lobsters Homarus americanus to odor solution in the presence of bleached kraft mill effluent. - J. Fish Res. Bd Can. 30, 279-282.

Miller, D., Brown, C. M., Pearson, T. H. \& Stanley, S. O., 1979. Some biologically important low molecular weight organic acids in the sediments of Loch Eil. - Mar. Biol. 50, 375-383.

Odum, E. P. 1969. The strategy of ecosystem development. - Ecology 164, 262-270.

Organisation for economic co-operation and development, 1973. Pollution by the pulp and paper industry. OECD, Paris, 129 pp.

Packard, T. T., Harmon, D. \& Boucher, J., 1974. Respiratory electron transfer activity in plankton from upwelled waters. - Téthys 6, 213.

Pearson, T. H., 1970. The benthic ecology of Loch Linnhe and Loch Eil, a sea-loch system on the west coast of Scotland. 1. The physical environment and distribution of the macrobenthic fauna. - J. exp. mar. Biol. Ecol. 5, 1-34.

Pearson, T. H., 1971a. Studies on the ecology of the macrobenthic fauna of Loch Linnhe and Eil, west coast of Scotland. II. Analysis of the macrobenthic fauna by comparison of feeding groups. Vie Milieu (Suppl.) 22, 53-91.

Pearson, T. H., 1971b. The benthic ecology of Loch Linnhe and Loch Eil, a sea-loch system on the west coast of Scotland. III. The effect on the benthic fauna of the introduction of pulp mill effluent. - J. exp. mar. Biol. Ecol. 6, 211-233.

Pearson, T. H., 1972. The effect of industrial effluent from pulp and paper mills on the marine benthic environment. - Proc. R. Soc. (B) 180, 469-485.

Pearson, T. H., 1975. The benthic ecology of Loch Linnhe \& Loch Eil, a sea-loch system on the west coast of Scotland. IV. Changes in the benthic fauna attributable to organic enrichment. $-J$. exp. mar. Biol. Ecol. 20, 1-41.

Pearson, T. H. Stress and catastrophe in marine benthic ecosystems. In: Proceedings of the stress ecology session of the 2nd international congress of ecology, Jerusalem, Sept. 1978. (In press.)

Pearson, T. H. Fjordic macrobenthos. In: Fjord oceanography. Ed. by D. Farmer \& H. J. Freeland. Plenum Press, New York (in press).

Pearson, T. H. \& Eleftheriou, A., 1980. The benthic ecology of Sullom Voe. - Proc. R. Soc. Edinb. (B) (in press).

Pearson, T. H. \& Rosenberg, R., 1976. A comparative study of the effects on the marine environment of wastes from cellulose industries in Scotland and Sweden. - Ambio 5, 77-79. 
Pearson, T. H. \& Rosenberg, R., 1978. Macrobenthic succession in relation to organic enrichment and pollution of the marine environment. - Oceanogr. mar. Biol. 16, 229-311.

Pearson, T. H. \& Stanley, S. O., 1979. Comparative measurement of the redox potential of marine sediments as a rapid means of assessing the effect of organic pollution.-Mar. Biol. 53, 371-379.

Poole, N. J., Wildish, D. J. \& Kristmanson, D. D., 1978. The effects of the pulp and paper industry on the aquatic environment. - Crit. Rev. environ. Control. 1978, 153-193.

Rainer, S. F., Ivanovici, A. M. \& Wadley, V. A., 1979. Effect of reduced salinity on adenylate energy charge in three estuarine molluscs. - Mar. Biol, 54, 91-99.

Rhoads, D. C. \& Young, D. K., 1970. The influence of deposit feeding organisms on sediment stability and community trophic structure. - J. mar. Res. 28, 150-178.

Rosenberg, R., 1971. Recovery of the littoral fauna in Saltkällefjorden subsequent to discontinued operations of a sulphite pulp mill. - Thallassia jugosl. 7, 341-351.

Rosenberg, R., 1972. Benthic faunal recovery in a Swedish fjord following the closure of a sulphite pulp mill. - Oikos 23, 92-108.

Rosenberg, R., 1973. Succession in benthic macrofauna in a Swedish fjord subsequent to the closure of a sulphite pulp mill. - Oikos $24,244-258$.

Rosenberg, R., 1974. Spatial dispersion of an estuarine benthic faunal community. - J. exp. mar. Biol. Ecol. 15, 69-80.

Rosenberg, R., 1976. Benthic faunal dynamics during succession following pollution abatement in a Swedish estuary. - Oikos 27, 414-427.

Sanders, H. L., 1969. Marine benthic diversity and the stability-time hypothesis. - Brookhaven Symp. Biol. 22, 71-81.

Schöttler, U., 1978. The influence of anaerobiosis on thelevels of adenosine nucleotides and some glycolytic metabolites in Tubifex sp. (Annelida, Oligochaeta).- Comp. Biochem. Physiol. 61B, 29-32.

Spies, R. B. \& Davis, P. H., 1979. The infaunal benthos of a natural oil seep in the Santa Barbara Channel. - Mar. Biol. 50, 227-237.

Stanley, S. O., Pearson, T. H. \& Brown, C. M., 1978. Marine microbial ecosystem and the degradation of organic pollutants. In: The oil industry and microbial ecosystems. Ed. by K. W. A. Chater \& H. J. Somerville. Heyden, London, 60-79.

Stanley, S. O., Grantham, B., Leftley, J. \& Robertson, N. Some aspects of sediment chemistry in Sullom Voe. - Proc. R. Soc. Edinb. (B) (in press).

Vance, I., 1978. Bacterial degradation of cellulose in marine sediments. Ph. D. thesis, Univ. of Dundee, $201 \mathrm{pp}$.

Vance, I., Stanley, S. O. \& Brown, C. M., 1979. A microscopical investigation of the bacterial degradation of wood pulp in a simulated marine environment. - J. gen. Microbiol. 114, 69-74.

Vosjan, J. H., 1974. Sulphate in water and sediment of the Dutch Wadden Sea. - Neth. J. Sea Res. 8, 208-213.

Walden, C. C., 1976. The toxicity of pulp and paper mill effluents and corresponding measurement proceedures. - Wat. Res. 10,639-645.

Waldichuk, M., 1978. Log pollution. - Mar. Pollut. Bull. 9, 313-314.

Waldichuk, M., 1979. Ecological impact of logs. - Mar. Pollut. Bull. 10, 33-34.

Whitfield. M., 1969. Eh as an operational parameter in estuarine studies. - Limnol. Oceanogr. 14, $547-558$.

Whitfield ${ }_{r}$ M., $_{1971}$. Ion selective electrodes for the analysis of natural waters. Austr. Mar. Sci. Ass. Sidney, $130 \mathrm{pp}$.

Widdows, J., 1978. Physiological indices of stress in Mytilus edulis. - J. mar. biol. Ass. U. K. 58, 125-142.

Wildish, D. J., Akagi, H. \& Poole, N. J., 1977. Avoidance by herring of dissolved components in pulp mill effluents. - Bull. environ. Contam. Toxicol. 18, 521-524.

Woelke, C. E., 1960. Effects of sulphite waste liquor on the normal development of Pacific oyster (Crassostrea gigas) larvae. - Res. Bull. Wash. St. Dep. Fish. 6, 150-161.

Wyatt, C. E., 1979. The ecology of ciliated protozoa from organically enriched marine sediments. $\mathrm{Ph}$. D. thesis, Univ. of Dundee, $314 \mathrm{pp}$.

Zimmermann, M. S. \& Livingston, R. J., 1976. Effects of kraft mill effluents on benthic macrophyte assemblages in a shallow-bay system (Apalachee Bay, North Florida, USA). - Mar. Biol. 34, $297-312$. 